\title{
Sinkronisasi Kurikulum Mata Kuliah Wajib Umum Pancasila, Kewarganegaraan, dan Agama di Perguruan Tinggi Dalam Melawan Radikalisme
}

\author{
Zulkarnain $^{1}$, Basri ${ }^{2}$, Matang ${ }^{3}$, Irawan Hadi Wiranata ${ }^{4}$ \\ ${ }^{1}$ zulkarnain@poltekba.ac.id, ${ }^{2}$ basri.dahlan@poltekba.ac.id \\ ${ }^{3}$ matang@umri.ac.id, ${ }^{4}$ wiranata@unpkdr.ac.id. \\ ${ }^{1,2}$ Politeknik Negeri Balikpapan \\ ${ }^{3}$ Universitas Muhammadiyah Riau \\ ${ }^{4}$ Universitas Nusantara PGRI Kediri
}

\begin{abstract}
Abstrak
Tulisan ini ingin menjelaskan tentang upaya yang seharusnya dilakukan oleh pengajar di perguruan tinggi untuk melawan dan menangkal berkembangnya paham radikalisme di perguruan tinggi dengan melakukan sinkronisasi kurikulum pada mata kuliah wajib umum seperti mata kuliah Pancasila, Kewarganegaraan, dan Agama. Penelitian ini menggunakan metode kualitatif deskriptif dengan pendekatan studi kasus. Penelitian ini dilakukan di pusat penjaminan mutu internal Politeknik Negeri Balikpapan bidang pengembangan kurikulum mata kuliah umum dalam melawan radikalisme dan tim dosen Pendidikan kewarganegaraan di luar Politeknik Negeri Balikpapan. Hasil dari penelitian ingin merekomendasi sinkronisasi kurikulum antara lain: pertama, sinkronisasi Rancangan pembelajaran semester khusus materi tentang radikalisme dalam Pancasila, Kewarganegaran, dan Pendidikan Agama, kedua melaksanakan hidden curriculum dalam melawan berkembangnya ideologi radikalis, ketiga melakukan evaluasi dan penelitian bersama tentang perkembangan radikalisme di perguruan tinggi secara berkelanjutan.
\end{abstract}

Kata kunci: Pancasila, Kewarganegaraan, Agama, Radikalisme, Kurikulum, Sinkronisasi.

\begin{abstract}
This paper wants to explain the efforts that lecturers should make in universities to fight and prevent the development of radicalism in universities by synchronizing the curriculum in general compulsory subjects such as Pancasila, Citizenship, and Religious education. This research uses a descriptive qualitative method with a case study approach. This research was conducted at the internal quality assurance center of the Politeknik Negeri Balikpapan in curriculum development for general courses in fighting radicalism and the civic education lecturer team outside the Politeknik Negeri Balikpapan. The results of the study would like to recommend curriculum synchronization, among others: first, synchronizing the design of semester learning materials about radicalism in Pancasila, Citizenship, and Religious Education, secondly implementing a hidden curriculum in countering the development of radicalist ideology, third conducting joint evaluations and research on the development of radicalism in higher education. Sustainable.
\end{abstract}

Keyword: Pancasila, Citizenship, Religious, Radicalism, Curriculum, Synchronization.

Peer reviewed under responsibility of Universitas Nusantara PGRI Kediri. (C) 2021 Zulkarnain, Basri, Matang, Irawan Hadi Wiranata

This is an open access article under the CC BY-SA license ( https://creativecommons.org/licenses/by-sa/4.0/ ) 
Jurnal PINUS: Jurnal Penelitian Inovasi Pembelajaran, 7 (1), 2021, Zulkarnain, Basri, Matang, Irawan Hadi Wiranata

\section{PENDAHULUAN}

Fakta tentang bahaya radikalisme menjadi fenomena yang sangat mengkhawatirkan. Masuknya paham radikalisme dalam lingkup dunia pendidikan khususnya pendidikan tinggi menunjukkan adanya ancaman nyata terhadap ideologi bangsa pada para penerus bangsa yakni mahasiswa. Dewasa ini mahasiswa merupakan salah satu sasaran utama gerakan pembawa ideologi ini. Tidak bisa dipungkiri ideologi banyak dianut dan digerakkan oleh kelompok-kelompok yang percaya kepada ajaran-ajaran agama tertentu (Ruslan, 2017). Gerakan radikalisme yang dimaksud dalam artikel ini adalah gerakan ideologi yang berbasis kesukuan, keagamaan maupun kelompok tertentu yang ingin melawan dan mengganti ideologi dan keyakinan yang berbeda menurut keyakinan yang dianut. Masyarakat diharapkan hidup berdampingan dalam bingkai kebhinekaan yang menjunjung nilai-nilai kemanusiaan dari pada memperdebatkan perbedaan ideologi atau perbedaan keyakinan (Wiranata \& Marzuki, 2018).

Dalam konteks Indonesia tentu gerakan Islam radikal tidak bisa kita pungkiri keberadaanya, tanpa ingin mengeneralisir Islam sebagai agama mayoritas dan identitas religius warga negara Indonesia (Zulkarnain, 201 7), namun pada kenyataanya gerakan Islam radikal di Indonesia banyak melakukan teror dan ancaman secara terbuka kepada pemerintah maupun kelompok tertentu dalam kurun waktu dua dekade terakhir (Suyanto et al., 2019). Istilah Islam radikal sering salah dipahami oleh banyak orang Islam pada umumnya, padahal yang dimaksud Islam radikal adalah orang-orang Islam secara individu atau kelompok yang menentang dan melawan semua ideologi selain ideologi, sistem politik dan hukum Islam, inilah yang dimaksud Islam radikal bukan mengatakan semua penganut Islam itu radikal. sejarah kekerasan dan radikalisme atas nama agama menunjukkan bagaimana kekuatan agama melebihi kekuatan sosial, budaya dan politik dalam sebuah masyarakat (Rodin, 2016). Sejarah agama mencatat selain Islam. Agama-agama besar seperti Kristen dan Yahudi memiliki sejarah panjang tentang gerakan fundamentalisme, kekerasan, intoleransi, dan radikalisme (Zuhairi, 2010), artinya sesungguhnya semua pemeluk agama memiliki potensi untuk melakukan gerakan radikalisme yang menjurus ke tindakan terorisme. Gerakan ini dalam melancarkan perlawanannya sering melakukan serangkaian teror dalam bentuk bom bunuh diri, penyerangan aparat kepolisian dan masyarakat sipil dengan motif untuk menunjukkan kekuatan dan keberanian dalam menggambil dan mengganti ideologi, sistem politik dan hukum Negara Republik Indonesia.

Salah satu kunci
besarnya gerakan ini $\begin{array}{r}\text { adalah } \\ \text { kemampuannya melakukan propaganda, }\end{array}$
agitasi, doktrinasi dan kaderisasi dengan
ajaran agama kepada banyak orang, salah
satunya adalah para mahasiswa dan
akademisi kampus yang kita anggap
sebagai kaum intelektual. Gerakan ini
melakukan propaganda dengan dalil-dalil
melakukan propaganda dengan dalil-dalil 
Jurnal PINUS: Jurnal Penelitian Inovasi Pembelajaran, 7 (1), 2021, Zulkarnain, Basri, Matang, Irawan Hadi Wiranata

yang ada dalam kitab suci yang membuat orang siap mati untuk melakukan apapun yang diperintahkan oleh kelompok tersebut. Bahkan dalam sebuah wawancara di stasiun televisi seorang mantan teroris mengatakan dia hanya butuh waktu dua jam saja untuk mendoktrin targetnya dan sang target sudah siap untuk melakukan bom bunuh diri sekalipun. Inilah buktinya betapa dahsyatnya kekuatan gerakan ideologi radikalisme berbasis agama dalam membangun loyalitas dan melakukan rekrutmen anggota baru. Radikalisme biasanya diawali dengan menyebarnya pemahaman dan tindakan intoleransi beragama di kalangan masyarakat yang pada akhirnya muncul sebagai sebuah gerakan ideologis radikal yang menampilkan keganasanya dalam bentuk teror yang kita kenal dengan terorisme pada saat ini (Hasani \& Naipospos, 2012; Supriadi et al., 2020).

Sejarah Indonesia mencatat gerakan radikalis berbasis agama sejak zaman awal kemerdekaan sampai runtuntuhnya orde baru dengan lahirnya berbagai ormas yang dengan nyata ingin mengganti ideologi negara Indonesia (Azami, 2018; Fealy, 2004; Nurhakiky \& Mubarok, 2019). Berdasarkan hasil penelitian terbarukan dalam beberapa tahun terakhir menunjukkan bahwa ideologi radikalis sudah masuk ke berbagai perguruan tinggi di Indonesia (Basri \& Dwiningrum, 2019; Murtadlo, 2019; Sirry, 2020). Berdasarkan hasil survei peneliti di 3 Perguruan Tinggi Negeri dan Swasta di Kota Balikpapan Berdasarkan hasil survei dengan jumlah responden 286 orang mahasiswa mengatakan bahwa selain ideologi Komunis dan Liberalis, ideologi Radikalis menjadi salah satu ideologi yang paling berbahaya, bahkan 50\% responden mengatakan hal yang sama, artinya bahwa ideologi ini bisa di indikasikan sudah masuk dan disadari keberadaannya oleh mahasiswa di perguruan tinggi meskipun jumlahnya sedikit dan terbatas.

Berdasarkan data yang dipublikasikan yang bersumber dari penelitian institusi resmi negara dan institusi kemasyarakatan menunjukkan beberapa perguruan tinggi di Indonesia sudah dimasuki ideologi radikalis dengan memanfaatkan semua sumber daya seperti himpunan mahasiswa dan himpunan diluar kampus namun masih berafiliasi dengan mahasiswa, ideologi ini sangat mudah dilihat dari perilaku intoleransi dan pemahaman agama yang eksklusif (Halili, 2019).

Berdasarkan hasil penelitian dan survei di atas menunjukkan gerakan radikalisme di perguruan tinggi masih berjalan, baik secara laten maupun secara terbuka. Salah satu kekuatan berkembangnya ideologi adalah dengan cara laten, artinya ideologi semakin kuat dan militan dilakukan dengan cara-cara yang tidak mudah dideteksi. Oleh sebab itu para pengajar di perguruan tinggi tidak bisa bekerja secara mandiri tanpa adanya sebuah sinkronisasi kurikulum pembelajaran khususnya pada mata kuliah dasar umum yang selanjutnya disebut dengan MKWU dimana berdasarkan Keputusan Direktur Jenderal Pendidikan Tinggi Kementerian Pendidikan dan Kebudayaan Republik 
Jurnal PINUS: Jurnal Penelitian Inovasi Pembelajaran, 7 (1), 2021, Zulkarnain, Basri, Matang, Irawan Hadi Wiranata

Indonesia Nomor 84/E/KPT/2020, Tentang Pedoman Pelaksanaan Mata Kuliah Wajib pada Kurikulum Perguruan Tinggi mewajibkan materi radikalisme sebagai salah satu materi penting dalam melawan berbagi bentuk radikalisme di Indonesia khususnya di perguruan tinggi. Namun pada kenyataannya banyak pengajar di perguruan tinggi belum melakukan sinkronisasi terkait kurikulum dalam memberikan kuliah tentang radikalisme. Pada matakuliah MKWU dalam penelitian ini PPKn dan Pendidikan Agama salah satu materi yang harus dimasukkan dalam pemebelajaran adalah materi tentang radikalisme.

Kurikulum

merupakan serangkain kegiatan yang terprogram yang sudah disusun, dirancang di evaluasi serta dikembangkan baik di sekolah maupun perguruan tinggi (Chalim, 2018). Berdasarkan Peraturan Perundangundangan Nomor 20 Tahun 2003 tentang Sistem Pendidikan menjelaskan bahwa kurikulum merupakan seperangkat rencana, pengaturan terkait tujuan, isi dan bahan pelajaran yang digunakan untuk mencapai tujuan pendidikan nasional. Kurikulum sesungguhnya tidak hanya mengenai perangkat pembelajaran akan tetapi juga tentang ideologi yang tertanam dan menggerakkan sebuah kurikulum. Hal ini tentu akan mempengaruhi proses dan hasil yang diharapkan.

Kurikulum merupakan salah satu bagian terpenting dalam sebuah proses pendidikan. Kurikulum bukan hanya sekedar perlengkapan pendidikan semata akan tetapi kurikulum merupakan sebuah upaya nyata dalam melakukan rekonstruksi sosial dalam dunia pendidikan (Azami, 2018), yang secara umum terdiri dari tujuan, konten, metode implementasi dan pengembangan kurikulum yang dilakukan secara terorganisir, semua elemen dalam kurikulum harus terintegrasi satu dengan yang lain sehingga tujuan akan tercapai dengan baik (Beauchamp, 1982).

Kurikulum dalam sebuah institusi Pendidikan baik sekolah maupun perguruan tinggi memiliki kekuatan untuk mereproduksi karakter dan membangun kontrol sosial pada peserta didik atau mahasiswa jika dilakukan dengan baik dan benar (Giroux, 1980). Oleh sebab itu kurikulum sangatlah memiliki pengaruh besar terhadap karakter dan pengetahuan mahasiswa. Komponen kurikulum yang terdiri dari tujuan, materi, metode dan evaluasi harus terintegrasi dengan baik. Begitu juga pengembangan kurikulum dalam Mata Kuliah Umum di perguruan tinggi di Indonesia yang terdiri dari Agama, Pancasila, Kewarganegaraan dan Bahasa Indonesia. Semua mata kuliah tersebut harus memiliki orientasi yang sama untuk melawan penyebaran paham radikalisme di perguruan tinggi oleh sebab itu sinkronisasi kurikulum khususnya materi dan metode sangatlah dibutuhkan untuk membunuh rantai penyebaran ideologi radikalis di perguruan tinggi.

Radikalisme tidak hanya berbahaya dalam bentuk tindakan kekerasan dan pengrusakan akan tetapi bahaya yang sering tidak diperhatikan adalah bahaya gerakan ideologi yang tidak tampak secara kasat mata, yang bergerak secara senyap dan masif. Inilah 
Jurnal PINUS: Jurnal Penelitian Inovasi Pembelajaran, 7 (1), 2021, Zulkarnain, Basri, Matang, Irawan Hadi Wiranata

masalah yang harus diatasi secara dini dan kurun waktu cepat dan berkelanjutan. Berdasarkan analisis artikel ini, penulis ingin merekomendasikan setidaknya tiga hal yang harus dilakukan oleh pengajar dalam melawan pergerakan ideologi di perguruan tinggi.

\section{METODE}

Penelitian Penelitian ini menggunakan pendekatan kualitatif deskriptif dengan pendekatan studi kasus dimana pada penelitian ini memfokuskan pada kasus sinkronisiasi kurikulum pada MKWU Pendidikan Pancasila dan Kewarganegaraan dan Pendidikan Agama Islam di Politeknik Negeri Balikpapan. Penelitian kaulitatif deskrptif ini dilakukan dengan menggunakan datadata kualitatif berupa hasil wawancara dan Forum Group Discussion (FGD) baik dengan tim mata kuliah wajib umum pada sistem penjaminan mutu internal Politeknik Negeri Balikpapan, serta dosen Pendidikan Kewarganegaraan di luar Politeknik Negeri Balikpapan sebagai masukan dalam pengembangan kurikulum mata kuliah umum. Data-data kaulitatif tersebut kemudian di dianalisis dan selanjutnya dipaparkan, dijabarkan secara deskriptif.

Dari hasil Wawancara dan $F G D$ tersebut peneliti menemukan upayaupaya yang harus dilakukan dalam melawan pergerakan ideologi radikalis di perguruan tinggi. Selain itu, penelitian didukung oleh data hasil suvei awal tentang pendapat mahasiswa tentang ideologi-ideologi berbahaya di Indonesia. Penelitian ini tidak hanya menghasilkan informasi tetapi menghasilkan produk konkrit dalam bentuk Rencana Pembelajaran Semeseter (RPS) yang sudah tersinkronisasi materi radikalis dalam mata kuliah Pendidikan Pancasila dan Kewarganegaran dan Pendidikan Agama Islam. Penelitian ini dimulai sejak bulan Mei sampai dengan bulan Juni tahun 2021 yang menghasilkan rekomendasi upaya melawan radikalisme dengan melakukan sinkronisasi kurikulum dalam penelitian ini.

\section{PEMBAHASAN}

Berdasarkan penelitian ini menunjukkan bahwa dibutuhkan beberapa langkah awal untuk melawan berkembangnya ideologi radikalisme antara lain sinkronisasi kurikulum antar mata kuliah wajib umum di perguruan tinggi berupa penyusunan rancangan pembelajaran semester bersama. Selain itu dibutuhkan hidden curriculum untuk melawan ideologi radikalis dan yang terakhir melakukan evaluasi bersama dan penelitian berkelanjutan tentang perkembangan ideologi radikalis pada mahasiswa di perguruan tinggi dan masyarakat pada umumnya.

Berdasarkan penelitian ini setidaknya ada tiga rekomendasi yang ditawarkan oleh artikel ini untuk melawan dan memutus rantai ideologi radikalisme melalui sinkronisasi antara lain sebagai berikut:

\section{Sinkronisasi Kurikulum Mata Kuliah Umum}

Melawan radikalisme di perguruan tinggi harus memiliki konsep dan cara, metode dan rencana yang baik dan matang. Salah satunya dengan mempersiapkan kurikulum 
Jurnal PINUS: Jurnal Penelitian Inovasi Pembelajaran, 7 (1), 2021, Zulkarnain, Basri, Matang, Irawan Hadi Wiranata

yang terintegrasi dan tersinkronisasi dengan mata kuliah yang terkait. Oleh sebab itu, upaya pertama yang harus dilakukan oleh pendidik sebelum melakukan upaya mendeteksi ideologi radikalisme pada mahasiswa ialah mempersiapkan kurikulum yang terintegrasi dan tersinkronisasi dengan baik. Upaya melawan radikalisme tidak bisa ditekankan hanya pada satu mata kuliah seperti Pendidikan Pancasila ataupun Pendidikan agama tertentu. Meskipun data membuktikan bahwa radikalisme ini sangat erat hubunganya dengan agama mayoritas di Indonesia yakni agama Islam atau biasa disebut dengan kelompok Daulah Islamiah (Masyithoh, 2016).

Berdasarkan Keputusan

Direktur Jenderal Pendidikan Tinggi Kementerian Pendidikan dan Kebudayaan Republik Indonesia Nomor 84/E/KPT/2020, tentang Pedoman Pelaksanaan Mata Kuliah Wajib Pada Kurikulum Perguruan Tinggi mewajibkan materi radikalisme sebagai materi pengembangan, dengan situasi dan kondisis perkembangan ideologi radikalis yang semakin menyebar sudah seharusnya materi radikalisme menjadi salah satu materi wajib pada mata kuliah wajib umum di perguruan tinggi. Hal ini sangat dibutuhkan dalam rangka menyatukan persepsi dan metode dalam pembelajaran khususnya tentang materi radikalisme di perguruan tinggi.

Sinkronisasi kurikulum mencakup antara lain sebagai berikut:

1. Menentukan tujuan pembelajaran yang sama dalam materi radikalisme;

2. Menggunakan metode pembelajaran yang efektif sesuai dengan karakteristik mata kuliah;

3. Menyatukan referensi dan persepsi tentang makan radikalisme yang kemudian dituangkan dalam modul pembelajaran yang disusun Bersama;

4. Memberikan contoh dan praktik yang sama tentang bahaya ideologi radikalis pada mahasiswa.

Empat tindakan sikronkronisasi ini harus lebih ditekankan pada mata kuliah umum seperti Pancasila, kewarganegaraan dan mata kuliah agama. Meskipun begitu matakuliah lain pun sesungguhnya memungkinkan untuk diselipkan materi radikalisme dalam rancangan kurikulumnya. Salah satu bentuk sinkronisasi itu adalah pengembangan Rencana Pembelajaran Semester (RPS) yang tersinkronisasi materi radikalisme dengan mata kuliah umum lainya.

Meskipun pengembangan kurikulum dalam bentuk RPS yang terintegrasi dengan mata kuliah lainya namun tim pengajar sangat jarang melakukan menyatukan persepsi dan referensi tentang makna 
Jurnal PINUS: Jurnal Penelitian Inovasi Pembelajaran, 7 (1), 2021, Zulkarnain, Basri, Matang, Irawan Hadi Wiranata

radikalisme dari sudut agama dan kebangsaan yang justru dalam keadaan tertentu terdapat kontradiksi makna yang berkembang di masyarakat. Hal semacam ini menjadi tantangan sendiri bagi para pengajar untuk tetap melakukan pembaharuan informasi terkait materi dan isu radikalisme dalam skala nasional dan internasional.

Kurikulum mata kuliah wajib umum di Politeknik Negeri Balikpapan mulai tahun ajaran 2021/2022 akan menggunakan kurikulum terintegrasi artinya semua mata kuliah melakukan sinkronisasi kurikulum terkait materi pembelajaran seperti radikalisme, taat pajak dan anti korupsi dalam rencana pembelajaran semesternya.

Berikut contoh sinkronisasi materi radikalisme dalam RPS online PPKn dan PAI di aplikasi Satuan Penjaminan Mutu Internal Politeknik Negri Blaikpapan.

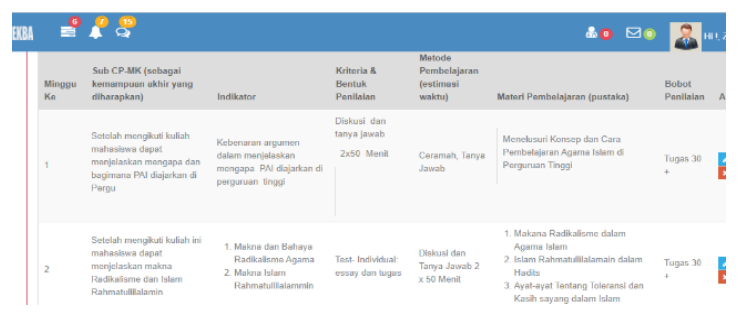

Gambar 1. RPS PAI yang tersinkronisasi Materi Radikalisme

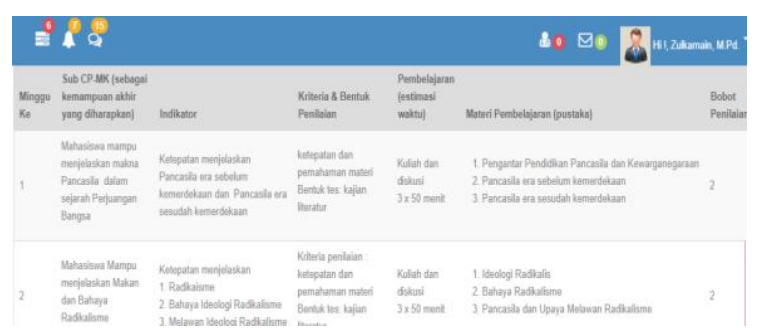

Gambar 2. RPS PPKn yang Tersinkronisasi Materi Radikalisme

\section{Hidden Curriculum}

Radikalisme tidak hanya bergerak secara terbuka akan tetapi sebagian besar ideologi ini bergerak secara laten atau tersembunyi dan sangat susah untuk dideteksi keberadaanya, artinya ideologi ini tidak mudah untuk ditaklukkan hanya dengan mengandalkan kurikulum resmi yang terancang dengan baik oleh para pengajar di perguruan tinggi, oleh sebab itu dibutuhkan sebuah kurikulum yang menunjang kurikulum resmi yakni kurikulum terselubung atau tersembunyi yang lumrah disebut hidden curriculum. Selain merancang dan melakukan sinkronisasi kurikulum dalam melawan radikalisme hidden curriculum sesungguhnya sangat membantu terlaksana tujuan kurikulum yang yang telah di susun secara resmi. Sayangnya kurikulum ini sering tidak diperhatikan oleh pengajar di sekolah dan perguruan tinggi dalam tercapainya tujuan pembelajaran yang yang seharusnya (Fitriani, 2017; Portelli, 1993).

Istilah hidden curriculum mulai dikenal sekitar tahun 1960 dan 1970 tentang bagaimana siswa dan mahasiswa bisa belajar sesuatu dari partisipasinya dalam kegiatan dan interaksinya dalam ruang lingkup sekolah atau perguruan tinggi (McLean \& Dixit, 2018). Hidden curriculum merupakan salah satu cara yang efektif untuk memproduksi perlawanan terhadap perkembangan ideologi tertentu dengan melakukan 
Jurnal PINUS: Jurnal Penelitian Inovasi Pembelajaran, 7 (1), 2021, Zulkarnain, Basri, Matang, Irawan Hadi Wiranata

hegemoni dan kontrol sosial (Apple, 2019; Null, 2011). termasuk melakukan reproduksi budaya kritis dalam menyikapi isu radikalisme bagi mahasiswa.

Hidden curriculum merupakan upaya yang tidak terencana oleh para pengajar di perguruan tinggi akan tetapi hal tersebut bisa sangat berpengaruh terhadap pemahaman dan praktek melawan radikalisme di perguruan tinggi. Kurikulum tersembunyi ini bisa berbentuk tugas ataupun projek sebagai pengganti perkuliahan ataupun bisa dalam bentuk kode etik yang diterapkan oleh jurusan ataupun program studi tertentu.

Salah satu pelaksanaan kurikulum tersembunyi yang pernah dilaksanakan di Politeknik Negeri Balikpapan pada mata kuliah Pendidikan Kewarganegaraan mahasiswa diminta untuk melakukan survei sebagai pengganti perkuliahan tentang pandangan siswa SMA dan Mahasiswa di Kota Balikpapan tentang ideologi yang mengancam eksistensi ideologi Pancasila, lalu dipresentasikan. Selain itu, beberapa mahasiswa juga diminta membagikan hasil bacaan atau pengalamanmu bergaul dengan kelompok keagamaan yang eksklusif, dimana kelompok ini hanya bergaul dengan kelompok yang sama pemahamannya saja, meskipun satu agama. Dari berbagai cerita dan pengalaman tersebut kita dapat merefleksikan apa saja yang bisa kita gunakan untuk mendeteksi ideologi radikalisme pada mahasiswa di perguruan tinggi.

Kurikulum tersembunyi ini sangat membantu mahasiswa memahami peraktik radikalisme dalam kehidupan sehari-hari yang berlandaskan pada agama tertentu, oleh sebab itulah sinkroniasi pada penelitian ini menitik beratkan pada mata kuliah umum Pancasila, Kewarganegaraan dan Mata Kuliah Keagamaan dalam hal ini Pendidikan Agama Islam di Politeknik Negeri Balikpapan.

\section{Evaluasi dan Penelitian Bersama}

Rekomendasi selanjutnya
dari penelitian ini adalah
melakukan evaluasi dan penelitian berkelanjutan tentang per-kembangan ideologi radikalis di perguruan tinggi.

Evaluasi merupakan salah satu bagian penting dalam Pendidikan dan pembelajaran baik di sekolah maupun diperguruan tinggi. Evaluasi merupakan suatu kegiatan yang direncanakan yang bertujuan untuk mengetahui keberhasilan proses pembelajaran yang telah dilakukan (Magdalena et al., 2020).

Dengan melakukan evaluasi kita dapat mengetahui kelemahan dan kekurangan dari 
Jurnal PINUS: Jurnal Penelitian Inovasi Pembelajaran, 7 (1), 2021, Zulkarnain, Basri, Matang, Irawan Hadi Wiranata

proses pembelajaran yang telah kita lakukan, sekaligus kita dengan akan mudah mendeteksi berbagai alternatif dalam mengatasi berbagai permasalahan tersebut (Suarga, 2019). Evaluasi dalam rangka membangun kurikulum yang terintegrasi tidak bisa dilakukan secara mandiri oleh dosen atau pengajar di perguruan tinggi. Setiap pengajar memiliki permasalahan dan kendala masing-masing dalam pembelajaran dengan materi yang sama yakni materi radikalisme. Oleh sebab itu evaluasi bersama dalam rangka mengetahui dan mencari solusi atas berbagai permasalahan. Salah satu bagian yang harus di evaluasi adalah kemampuan kritis mahasiswa dalam memahami materi radikalisme, karena evaluasi bertujuan untuk menegatahui tingkat kemampuan analisisi kritis mahasiswa dalam memahami materi yang sudah diberikan (Putera, 2018). Hal ini wajib dilakukan secara bersama dan secara berkesinambungan.

Penelitian bersama merupakan rekomendasi terakhir yang tawarkan dalam penelitian baik penelitian bersama tentang penelitian yang berbasis kelas dan penelitian bersama berbasis lapangan atau masyarakat. Hal ini dibutuhkan untuk mendeteksi berbagai pergerakan dan perubahan cara penyebaran ideologi radikalisme di masyarakat dan perguruan tinggi. Evaluasi dan dan penelitian bersama secara berkesinambungan akan membangun kolaborasi para pengajar dalam mendesain bersama kurikulum yang tepat dimasa yang akan datang (Voogt et al., 2016).

Salah satu cara yang efektif dalam melakukan evaluasi dan penelitian bersama secara berkelanjutan adalah dengan melakukan evaluasi bersama setiap mahasiswa baru dan mahasiswa yang lama baik secara terintegrasi dengan evaluasi di akhir semester ataupun tersipisah, evaluasi ini hendaknya dilakukan minimal satu kali dalam setahun dengan instrument yang di susun bersama dalam rangka mendeteksi pemahaman radikalisme di perguruan tinggi. Selanjutnya melakukan penelitian bersama dengan membuat roadmap penelitian tentang perkembangan ideologi radikalis di masyarakat dan dunia Pendidikan secara berkelanjutan sesuai dengan Roadmap yang sudah disusun bersama.

\section{KESIMPULAN}

Berdasarkan

Sinkronisasi kurikulum dalam mata kuliah umum pada perguruan tinggi menjadi sebuah kewajiban yang tidak bisa dihindari pada umumnya, khususnya dalam upaya melawan tumbuh dan berkembangnya ideologi radikalis di perguruan tinggi. Melawan ideologi ni tidak bisa hanya mengandalkan hanya pada mata kuliah tertentu, harus ada kesepakatan dan upaya bersama dalam melawan isu radikalisme 
Jurnal PINUS: Jurnal Penelitian Inovasi Pembelajaran, 7 (1), 2021, Zulkarnain, Basri, Matang, Irawan Hadi Wiranata

ini sebagai sebuah pekerjaan Bersama, oleh sebab itulah sinkronisasi kurikulum pada mata kuliah umum seperti mata kuliah Pancasila, Kewarganegaraan dan Agama menjadi sebuah kewajiban yang seharusnya dilaksanakan sebagai seorang pengajar mata kuliah umum di perguruan tinggi.

Sinergi yang kuat dan terencana melalui sinkronisasi kurikulum akan mempermudah pengajar dalam mendeteksi dan mengatasi berbagai bentuk penyebaran ideologi radikal di perguruan tinggi. Sinkronisasi ini sesungguhnya bisa dilakukan diberbagai mata kuliah yang serumpun dengan tujuan dan maksud yang sama. Karena keterbatasan kemampuan peneliti, maka penelitian ini hanya memfokuskan pada pengembangan sinkronisasi kurikulum pada mata kuliah Pancasila, Kewarganegaraan dan Agama Islam di perguruan Tinggi.

\section{DAFTAR RUJUKAN}

Apple, M. W. (2019). Ideology and Curriculum (4th ed.). Taylor \& Francis Books. https://doi.org/10.4324/9780429400 384

Azami, T. (2018). Kurikulum Kontra Radikalisme. In UIN Walisongo Semarang. UIN Walisongo Semarang.

Basri, B., \& Dwiningrum, N. R. (2019). Potensi Radikalisme di Perguruan Tinggi (Studi Kasus di Politeknik Negeri Balikpapan). JSHP: Jurnal Sosial Humaniora dan Pendidikan, 3(1), 84-91. https://doi.org/10.32487/jshp.v3i1.5 46
Beauchamp, G. A. (1982). Curriculum Theory: Meaning, Development, and Use. Theory into Practice, 21(1), 23-27. https://doi.org/10.1080/0040584820 9542976

Chalim, S. (2018). Terhadap Perilaku Anti-Radikalisme Mahasiswa the Impact of University's Mission, Curriculum, and Leadership Toward Students ' View of AntiRadicalism. Jurnal Pendidikan Dan Kebudayaan, 3(2013), 33-43. https://doi.org/10.24832/jpnk.v3i1.7 28

Fealy, G. (2004). Islamic Radicalism in Indonesia: The Faltering Revival? Author (s): Greg Fealy Source: Southeast Asian Affairs, (2004), pp . 104-121 Published by: ISEAS Yosuf Ishak Institute Stable URL: http://www.jstor.org/stable/279132 55 The Faltering Reviv. 2004, 104 121.

Fitriani, E. (2017). Implementasi Hidden Curriculum dalam Pembentukan Karakter Religius Peserta Didik. Universitas Islam Negeri Maulana Malik Ibrahim.

Giroux, H. A. (1980). Critical Theory and Rationality in Citizenship Education. Curriculum Inquiry, 10(4), 329-366. https://doi.org/10.1080/03626784.1 980.11075229

Halili. (2019). Wacana dan Gerakan Keagamaan di Kalangan Mahasiswa. Https://SetaraInstitute.Org, 1-9. https://setarainstitute.org/wacana-dan-gerakankeagamaan-di-kalanganmahasiswa-2/

Hasani, I., \& Naipospos, B. T. (2012). Dari Radikalisme Menuju Terorisme Studi Relasi dan Transformasi Organisasi Islam Radikal Di Jawa Tengah \& D.I. 
Jurnal PINUS: Jurnal Penelitian Inovasi Pembelajaran, 7 (1), 2021, Zulkarnain, Basri, Matang, Irawan Hadi Wiranata

Yogyakarta. Setara Institute.

Magdalena, I., Fauzi, H. N., Putri, R., \& Tangerang, U. M. (2020). Pentingnya Evaluasi dalam Pembelajaran Dan Akibat Memanipulasinya. Bintang: Jurnal Pendidikan Dan Sains, 2, 244-257.

Masyithoh, N. D. (2016). Dialektika Pluralisme Hukum: Upaya Penyelesaian Masalah Ancaman Keberagaman dan Keberagamaan di Indonesia. Walisongo: Jurnal Penelitian Sosial Keagamaan, 24(2), 359-378.

McLean, S., \& Dixit, J. (2018). The Power of Positive Thinking: A Hidden Curriculum for Precarious Times. Adult Education Quarterly, 68(4), 280-296. https://doi.org/10.1177/0741713618 777817

Murtadlo, M. (2019). Menakar Moderasi Beragama di Perguruan Tinggi. Badan Litbang Dan Diklat Kementerian Agama RI.

Null, W. (2011). Curriculum from Theory to Practice. Rowman \& Littlefield Publishers.

Nurhakiky, S. M., \& Mubarok, M. N. (2019). Pendidikan Agama Islam Penangkal Radikalisme. IQ (Ilmu Al-Qur'an): Jurnal Pendidikan Islam, 2(01), 101-116. https://doi.org/10.37542/iq.v2i01.27

Portelli, J. P. (1993). Exposing the Hidden Curriculum. Journal of Curriculum Studies, 25(4), 343-358. https://doi.org/10.1080/0022027930 250404

Putera, E. P. (2018). Pengaruh Media Sosial sebagai Sumber Belajar IPS Terhadap Motivasi Belajar, Kemampuan Berpikir Kritis dan Berpikir Kreatif Siswa Sekolah Dasar. Jurnal PINUS, 4(1), 54-59. http://dx.doi.org/10.1016/j.cirp.201 6.06.001\%0Ahttp://dx.doi.org/10.1
016/j.powtec.2016.12.055\%0Ahttps ://doi.org/10.1016/j.ijfatigue.2019.0 2.006\%0Ahttps://doi.org/10.1016/j. matlet.2019.04.024\%0Ahttps://doi. org/10.1016/j.matlet.2019.127252\% 0Ahttp://dx.doi.o

Rodin, D. (2016). Islam dan Radikalisme: Telaah atas Ayat-ayat "Kekerasan" dalam al-Qur'an. Addin, 10(1), 29. https://doi.org/10.21043/addin.v10i 1.1128

Ruslan, I. (2017). Islam dan Radikalisme: Upaya Antisipasi dan Penanggulangannya. Kalam, 9(2), 215.

https://doi.org/10.24042/klm.v9i2.3 29

Sirry, M. (2020). Muslim Student Radicalism and SelfDeradicalization in Indonesia. Islam and Christian-Muslim Relations, $31(2)$, 241-260. https://doi.org/10.1080/09596410.2 020.1770665

Suarga, S. (2019). Hakikat, Tujuan dan Fungsi Evaluasi dalam Pengembangan Pembelajaran. Inspiratif Pendidikan, 8(1), 327338.

https://doi.org/10.24252/ip.v8i1.784 4

Supriadi, E., Ajib, G., \& Sugiarso, S. (2020). Intoleransi dan Radikalisme Agama: Konstruk LSM tentang Program Deradikalisasi. JSW (Jurnal Sosiologi Walisongo), 4(1), 53-72.

https://doi.org/10.21580/jsw.2020.4 .1 .4544

Suyanto, B., Sirry, M., \& Sugihartati, R. (2019). Pseudo-Radicalism and the De-Radicalization of Educated Youth in Indonesia. Studies in Conflict and Terrorism, O(0), 1-20. https://doi.org/10.1080/1057610X.2 019.1654726

Voogt, J. M., Pieters, J. M., \& 
Jurnal PINUS: Jurnal Penelitian Inovasi Pembelajaran, 7 (1), 2021, Zulkarnain, Basri, Matang, Irawan Hadi Wiranata

Handelzalts, A. (2016). Teacher Collaboration in Curriculum Design Teams: Effects, Mechanisms, and Conditions. Educational Research and Evaluation, 22(3-4), 121-140. https://doi.org/10.1080/13803611.2 016.1247725

Wiranata, I. H., \& Marzuki, M. (2018).

Kerukunan Antarumat Beragama Sebagai Dasar City Branding Harmoni Kediri The Service City. Jurnal Ilmiah Pendidikan Pancasila dan Kewarganegaraan, 3(1), 64-73.

zuhairi, M. (2010). Al-Qur'an Kitab

Toleransi: Tafsir Tematik Islam Rahmatulil 'alamin. Kompas Gramedia.

Zulkarnain. (2017). Warga Negara Religius sebagai Identitas Kewarganegaraan di Indonesia. Pendidikan Pancasila Dan Kewarganegaraan UNY, November, 38-44. 